\title{
Implementing the African Continental Free Trade Area (AfCFTA): The Effects of Trade Procedures on Trade Flows
}

\author{
Manfred Kouty, ${ }^{1, *}$ \\ ${ }^{1}$ International Relations Institute of Cameroon (IRIC), University of Yaounde 2, Cameroon \\ *Corresponding author: International Relations Institute of Cameroon (IRIC), University of \\ Yaounde, Cameroon. Tel: 237-677-302-892. E-mail: koutymanfred@yahoo.fr
}

Received: April 9, 2020 Accepted: April 21, 2020 Published: March 20, 2021

doi: 10.5296/rae.v13i1.18468ＵRL: https://doi.org/10.5296/rae.v13i1.18468

\begin{abstract}
In January 2018, the 10th African Union (AU) Summit of African Heads of States and Governments was held in Kigali. At this occasion, 44 countries had signed the African Continental Free Trade Area (AfCFTA) agreement. In this study, it is pointed out that the implementation of AfCFTA cannot be done without harmonized trade procedures. Using a gravity model of 49 African countries over the 2010-2015 periods, the study estimates the impact of inefficient trade procedures on intra-African trade. The results show that trade procedures such as the number of documents required to import goods and Border compliance negatively affect intra-African trade. This suggests the need of harmonization and rationalization of trade procedures to boost intra-African trade.
\end{abstract}

JEL Classification: C33; F13; F15; H32; O55.

Keywords: trade procedures, regional integration, AfCFTA, gravity model 


\section{MlMacrothink}

\section{Introduction}

Long time before the establishment of the African Union (AU) in 2000, regional integration was a key policy agenda item across the African continent. The adoption of the Lagos Plan of Action in 1980 was a major framework for the achievement of this goal. But the Abuja Treaty (1991) which establishes the African Economic Community (AEC) appears to be the main legal framework of continental integration. According to the Abuja treaty, African countries committed themselves to establish the AEC gradually in six stages (Figure 1).

The first stage consists of strengthening the existing Regional Economic Communities (RECs) and creating new ones where needed (1994-1999). This stage had to last five years from 1994 to 1999 . The second stage includes the stabilization of tariff and other barriers to regional trade and the strengthening of sectoral integration (particularly in the field of trade, agriculture, finance, transport and communication, industry and energy) as well as coordination and harmonization of the activities of the RECs. This stage ended in 2007. The third stage concerns the Establishment of a free trade area and a Customs Union at the level of each REC (2007-2017). The fourth stage take into account the coordination and harmonization of tariff and non-tariff systems among RECs, in a view of establishing a Continental Customs Union (2017-2019). The fifth stage is related to the establishment of an African Common Market and the adoption of common policies (2019-2023). Finally, the last stage takes into account the establishment of the African Economic Community and the creation of other institutions like the African Monetary Union and the Pan-African Parliament (2023-2028).

However if we can consider that the first stage has been now completed with eight RECs(note 1) formally recognized by the African Union, we cannot say the same for the other stages and in particular step 3. According to the United Nations (UN), AU and African Development Bank (2017) report, the second stage has not been totally achieved and only three (ECOWAS, EAC and COMESA) of the eight recognized RECs have both a FTA and Customs Union as expected at third stage.

This is the reason why since2010, the African Ministers of Trade have recommended to fast-track the regional integration agenda and proposed the establishment of a Continental Free Trade Area (CFTA) by 2017 (Mevel and Karingi, 2012; ECA, 2016). This commitment was reaffirmed in January 2012 during the 18th African Union Summit held in Addis Ababa in which the Heads of States and Governments had endorsed a declaration on "Boosting Intra-African Trade and the Establishment of a Continental Free Trade Area" (African Union, 2013). 
Stage 1: Strengthen existing RECs and establish new RECs In reglons where they do not exist (by 1999)

Stage 2: Ensure consolidation within each REC (gradual removal of tariff and non-tarlff barrlers) and harmonization between the RECs (by 2007)

Stage 3: Establlsh FTAs and Customs Unlons (CUs) In each REC (by 2017)

Stage 4: Coordlnate and harmonize tarlff and non-tariff systems among the RECs with a vlew to creating a continental CU (by 2019)

Stage 5: Create an African Common Market (ACM) by 2023

Stage 6: Establish an AEC, Including an African Monetary Unlon and a Pan-African Parllament (by 2028)

Figure 1. Roadmap towards an African Economic Community

Source: ECA(2016).

Even if the African Continental Free Trade Area (AfCFTA) does not feature explicitly in the Abuja Treaty, in accordance with the sequential stages of regional economic integration, it is an important way to catch up with stage 4 which relates to the creation of Continental Customs Union. Also considered as a keystone initiative of AU's Agenda 2063, the agreement establishing the AfCFTA was signed by 44 countries at a summit of the African Unionheld in Kigali (Rwanda) in March 21, 2018. The agreement officially entered into force in 2019 and its implementation is effective since the first January 2021(note 2).

As mentioned in article 3 of the AfCFTA agreement, the key objective of the AfCFTA is to boost intra-African trade. However this objective cannot be achieved if some challenges are not addressed among which the setting up of a single continental legal trade regime. This include the harmonization of trade procedures (AU, 2013; UNCTAD, 2019). Article 20 of the annex 4 on trade facilitation of AfCFTA agreement clearly states that "each State Party shall, subject to paragraph 2, apply uniform import, export, and transit procedures and uniform documentation requirements for release of goods throughout its territory".

The recent economic literature emphasizes that, trade procedures related to international trade transactions represent a major obstacle to trade in Africa where customs and administrative processes are inefficient and differ from country to country (WTO, 2015; UNCTAD, 2019). Harmonization of the mentioned trade procedures is therefore one of the big challenges of the AfCFTA. The objective of this study is to evaluate and analyze the effects of inefficient trade procedures on trade volumes between African countries. The study uses gravity model of 49 African countries over the 2010-2015 periods. The findings suggest that trade procedures 


\section{Macrothink

such asthe number of documents required to import goods and Border compliance negatively affect intra-African trade. The rest of the paper proceeds as follows: the next section presents the brief review of the literature. This is followed by the empirical analysis of trade procedures in African countries. The econometrics analysis is presented in Section 4. Section 5 outlines the results and Section 6 concludes.

\section{Literature Review}

Extensive literature reviews can be found in Zaki (2007), Bourdet and Persson (2012), Donaldson et al. (2017). We define briefly the trade procedures and discuss the empirical studies.

\section{a. What is trade procedures and what does it involve?}

In its simplest form, trade procedures involve all measures facilitating the import of parts and components and their movement to production, as well as all measures facilitating the export of the processed good from the production to the port (Figure 2). Trade procedures harmonization refers to the process of eliminating all unnecessary elements and duplication in trade formalities, processes and procedures (WTO, 2015).

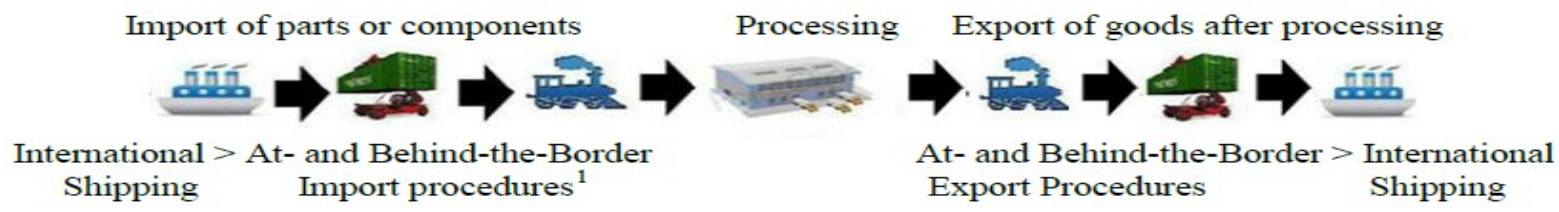

Figure 2. Trade Procedures in an International Production Network Context

Sources: ESCAP (2013).

Trade procedures harmonization is one of the four fundamental principles of Trade Facilitation (Figure 3). 


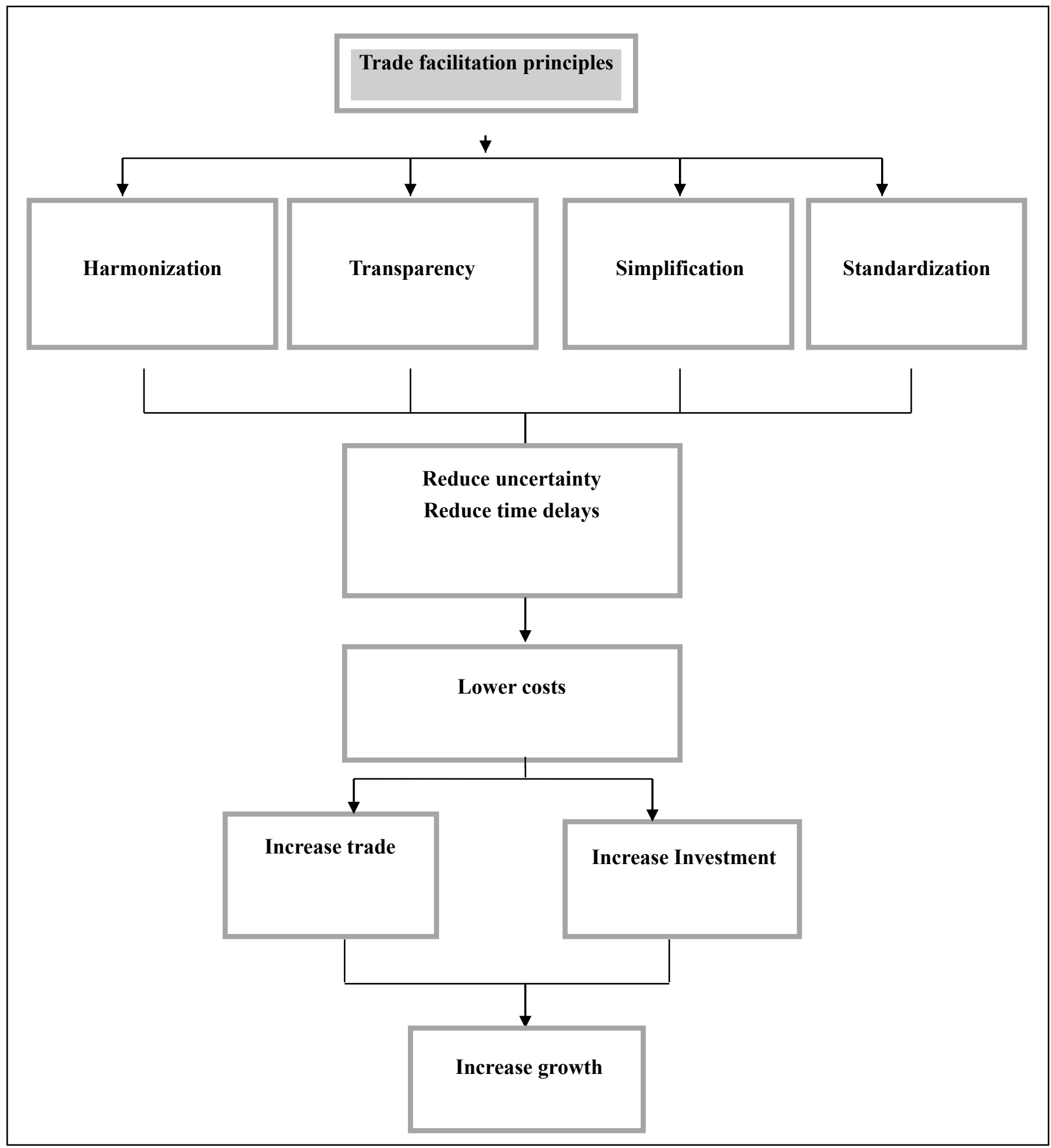

Figure 3. Trade Facilitation and Economic Outcomes

Source: Author's work based on literature.

The latter being defined by the WTO (2015) as the simplification and harmonization of international trade procedures covering the activities, practices and formalities involved in collecting, presenting, communicating and processing data required for the movement of 
goods in international trade. Like other measures of trade facilitation, trade procedures harmonization reduce delays (reduce the time needed for travel, border-crossings and administrative procedures) and uncertainty (availability of information, enhancing predictability), thereby lowering costs for both importers and exporters. These lower trading costs in turn increases productivity and positively affects trade flow and investment. Trade expansion and investment contribute to economic growth and generate income for poverty reduction Europe (AfDB, AU and ECA,2013).

\section{b. Previous research}

The empirical literature on the effects of trade procedures on trade relies to the literature of trade facilitation. Many authors (Moïsé and Sorescu, 2013; Hummels and Schaur, 2013; Seetanah et al., 2016), highlights the importance of trade facilitation for economic development and regional integration. Empirically, the literature distinguishes two approaches to analyze the effect of trade facilitation on trade: the bottom up approach and the top down approach.

The bottom up approach was developed by Anderson and Van Wincopp (2003) who used the gravity model to determine the fundamental trade facilitation factors that have a significant impact on bilateral trade flows. These factors are directly observable data or proxy of trade facilitation variables. Anderson and Van Wincopp (2003) found that trade costs represent an equivalent tax of $170 \%$ for industrialized countries and came to the conclusion that the border-related trade barriers, wholesale and retail distribution costs and transportation costs are the main factors that negatively affect bilateral trade flows.

Following Anderson and Van Wincopp (2003) approach, Moïsé and Sorescu (2013) found that formalities relating to procedures, and formalities in documents, exhibit among the highest and most robust impacts on trade flows and trade costs in developing countries. Other authors like Djankov et al. (2010) investigated the effect of time on trade and found that each additional day that a product is delayed prior to being shipped reduces trade by more than one percent. Bourdet and Persson (2012), estimate the impact of trade procedures on exports from non-EU countries and found that harmonization could have substantial trade effects. Freund and Rocha (2010) used detailed data on transit, documentation and customs delays on Africa's exports and found that a one-day reduction in inland travel times led to a 7 per cent increase in exports. This result is consistent with the findings of Hummels and Schaur (2013) who suggested in their study that the reduction of transit time by one day could drive trade at a magnitude equivalent to a reduction in the advalorem tariff by 0.6 to 2.1 per cent.

The top down approach was developed by Novy (2013) and extended by Arvish et al. (2013). This approach contrasts with the "bottom up" in the sense that it infers overall trade costs indirectly from trade data without distinguishing between cost components (transport costs, costs associated with completing trade procedures and the delay behind-the-border etc.). This indicator captures all trade costs components that have been impossible to include in the gravity framework. After building a bilateral trade costs of many countries, the trade costs indicator is in turn used in the gravity model in order to estimate its effect on trade flows. Using the top down approach, Arvishet al. (2013) found evidence that Sub-Saharan African 


\section{Al Macrothink

countries and low income countries are subject to very high levels of trade costs and this explains their slow participation in international trade. Similarly, Kouty (2018) suggest that a country's ability to reduce trade costs and increase trade globally depends on its connectivity on international supply chain. The quality of supply chain connectivity of a country is based on the trading across border indicators (number of documents, time, and cost involved) and the Liner Shipping Connectivity Index (LSCI).

\section{Trade Procedures in African Countries: What Does Data Show?}

In this section we present some findings of trade procedures indicators in Africa. Generally, trade procedures are based on the Trading Across Border (TAB) indicators of World Bank. The TAB indicators include: the documents required to export and import measured in number, the time required to export and import measured in days, and the cost required to export and import measured in us dollars per container. Figure 4 shows the average time to clear export through customs in some regions in the world. We need in average ten days to clear direct exports through customs in Sub-Saharan Africa. This is too high compared to other regions such as Central Europe in which the procedures take only 4 days.

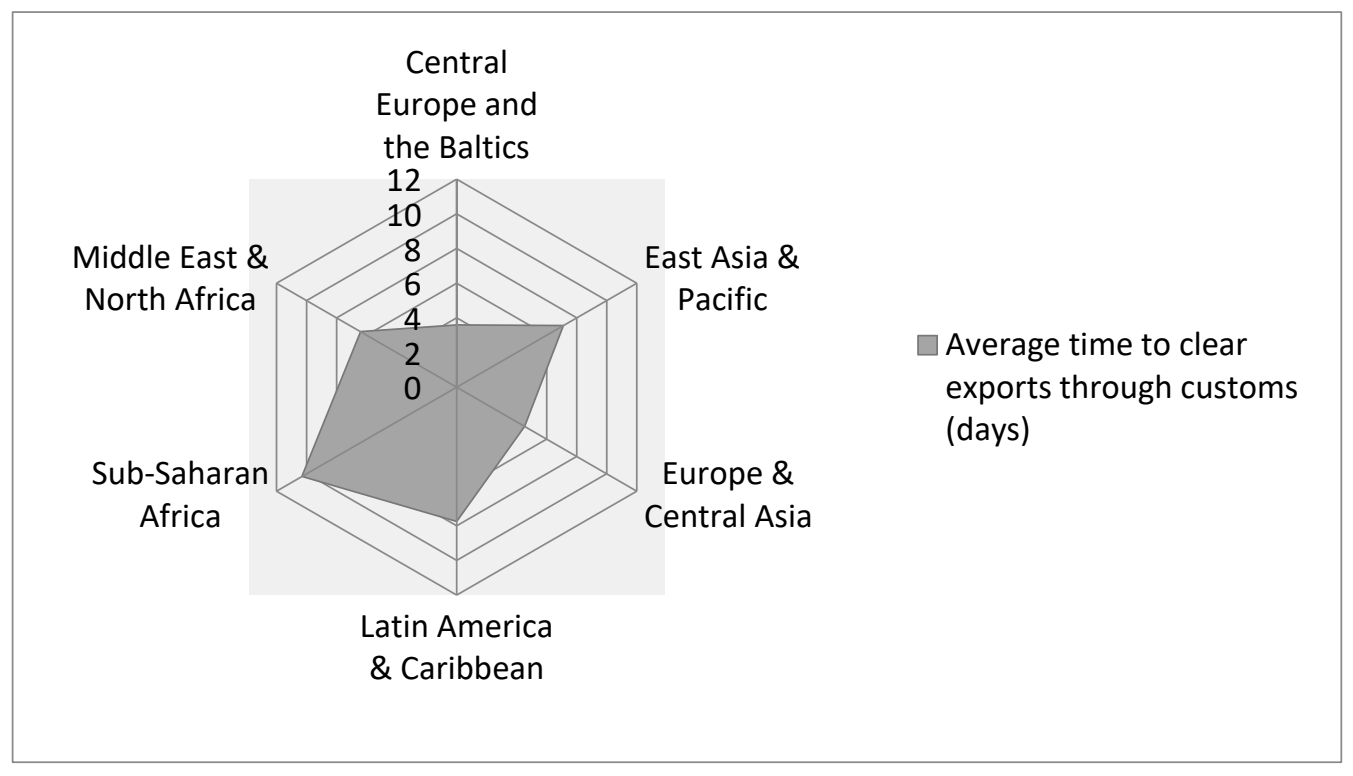

Figure 4. Average Time to Clear Exports Through Customs (2017)

Source: World bank data(note 3).

This long delay in Sub-Saharan Africa may be justified by the cumbersome border-crossing procedures. Figure 5 shows that the number of documents required to export (8) and import (9) is higher in Africa than in any other region. 


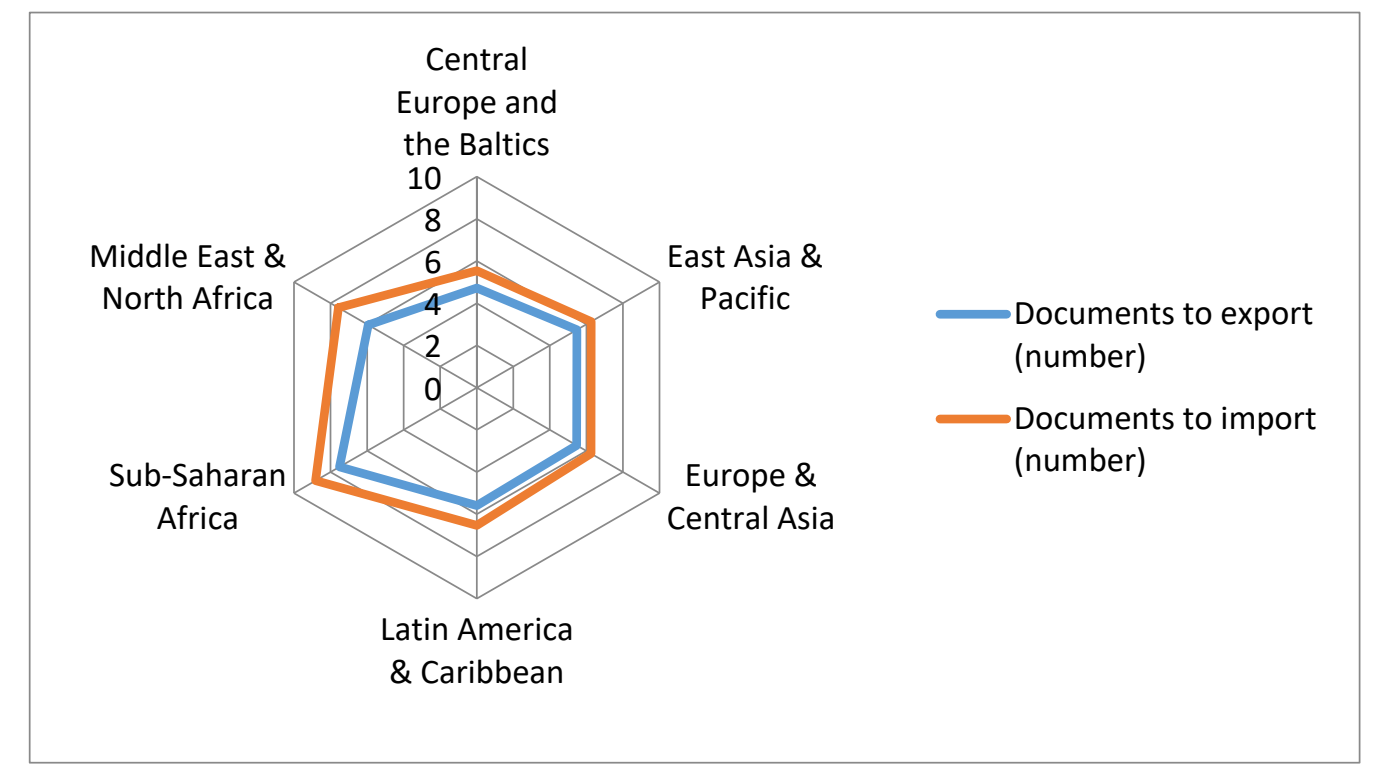

Figure 5. The Number of Documents to Export and Import Goods (2017)

Source: World Bank data

The cumbersomeborder-crossing negatively affects the custom efficiency. As figure 6 and 7 show, Sub-Saharan Africa and, Latin America and Caribbean arethe two regions where the customs procedures are the least efficient.

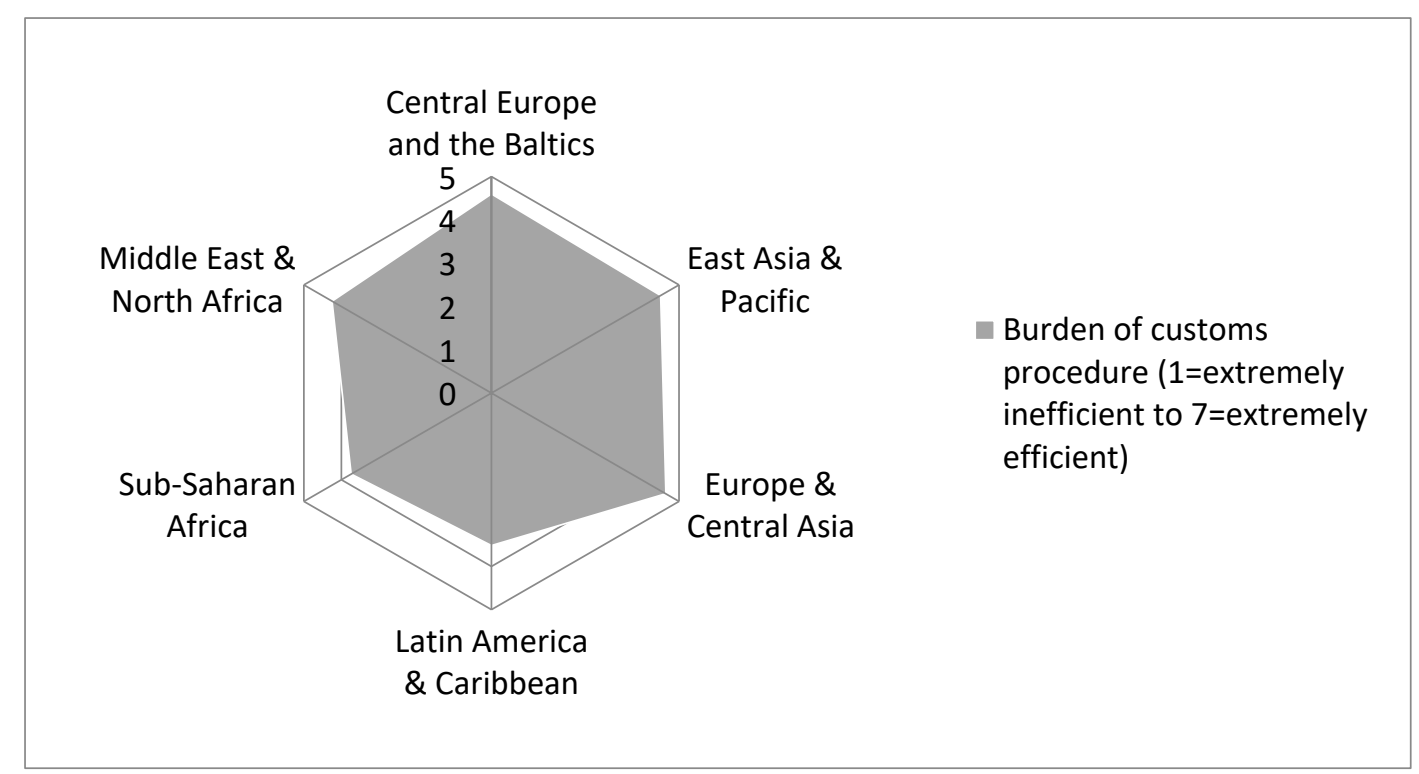

Figure 6. Burden of Custom Procedure (2014)

Source: World Economic Forum data. 


\section{Macrothink}

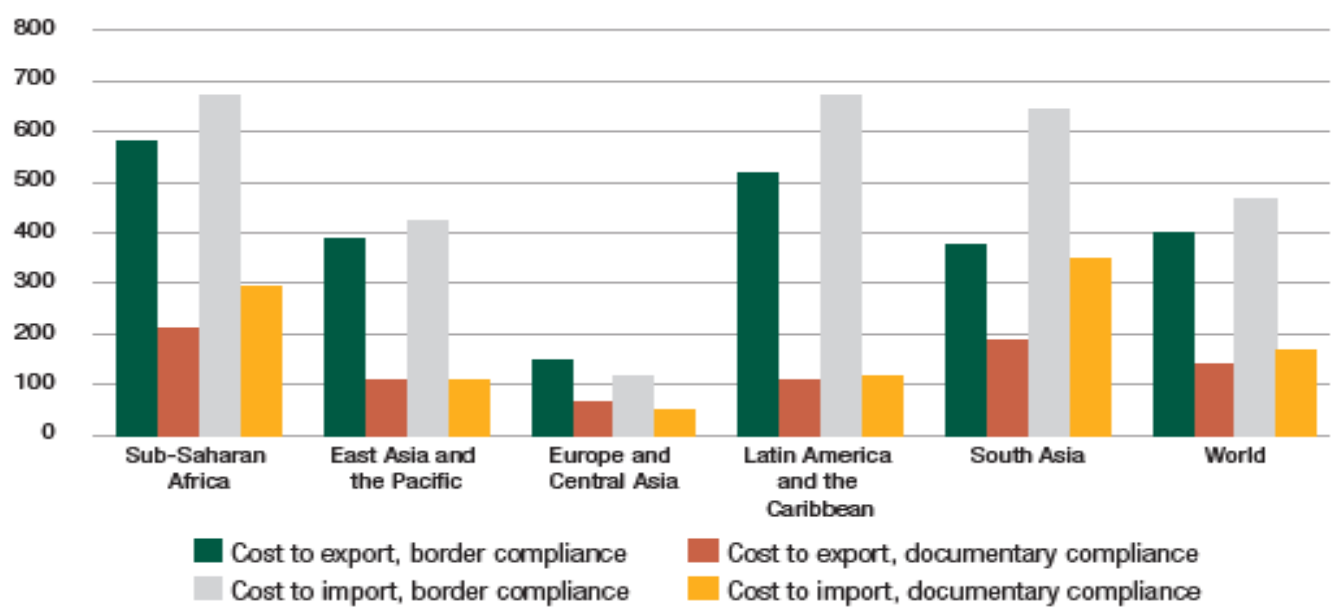

Figure 7. Cost to Import and Export by Region, 2016 (Dollars)

Source: UNCTAD (2019).

In short, the cumbersome border-crossing procedures and delays add to the overall costs of intra-African trade. Consequently, Africa is one of the regions in the world that trade little with itself (Figure 8).

Since the last three decades, African countries have seen massive trade liberalization, but the inefficient trade procedures continue to increase the cost of moving goods within the continent. Sub-Saharan African countries have the lowest trade among themselves compared with other regions. Intra-regional trade is estimated at about $18 \%$ compared with $55 \%$ in America, 59\% in Asia and 69\% in Europe(note 4). Toboost trade among themselves, African countries should harmonize procedures.

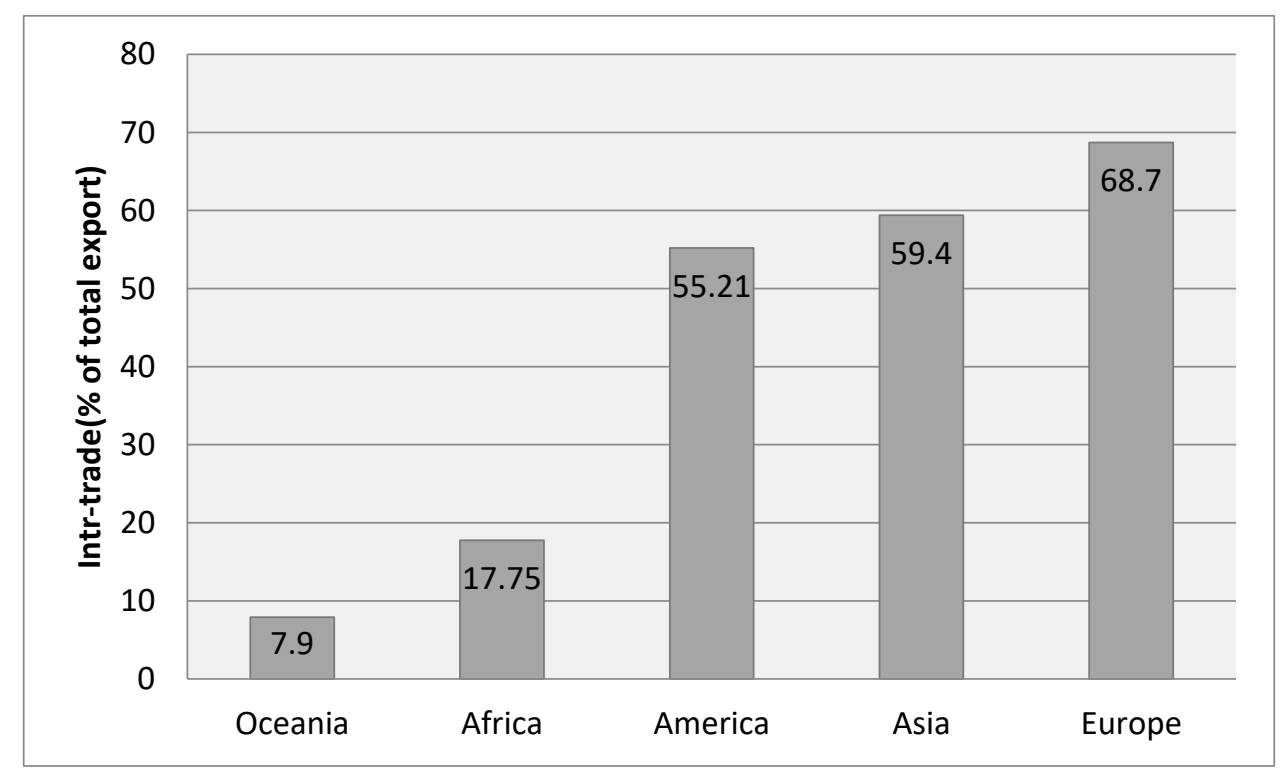

Figure 8. Intra-trade by Region in 2016

Source: UNCTADSTAT(note 5). 


\section{1) Macrothink}

\section{Econometrics Analysis}

With the basic analyses conducted so far, it is impossible to determine how trade procedures influence trade. To address this issue, we use a gravity model that allows to analyze the impact of trade procedures on intra-African trade flows. Following Anderson et Van Wincoop (2003), our regression equation takes the form:

$$
X_{i j}=\frac{Y_{i} Y_{j}}{Y}\left(\frac{t_{i j}}{P_{i} \Pi_{j}}\right)^{1-\sigma}
$$

where $X_{i j}$ denotes nominal exports from country $j$ to $i, Y_{i}$ and $Y_{j}$ are the exogenously given GDP's per capita of the two countries respectively, $Y$ the is the world GDP, and $\sigma$ is the elasticity of substitution across goods $(\sigma>1)$. The terms $\Pi_{i}, P_{j}$ represent price indices(note 6 ) in countries $i$ and $j$ respectively while the expression $t_{i j}$ denotes bilateral trade costs. Given the multiplicative nature of the gravity equation, the standard procedure for estimating a gravity equation (1) is simply to take the natural logarithms of all variables and obtain a log-linear equation that can be estimated by ordinary least squares regression. This yields the estimation equation:

$$
\ln X_{i j}=a_{0}+a_{1} \ln Y_{i}+a_{2} \ln Y_{j}+a_{3} \ln t_{i j}+a_{4} \ln P_{i}+a_{5} \ln \Pi_{j}+\varepsilon_{i j}
$$

where $a_{0}$, is a constant, $a_{3}=1-\sigma$ and $\varepsilon_{i j}$, is the error term.

In practice, the bilateral trade costs and the multilateral resistance variables is used as proxy by bilateral distance and dummies for islands, landlocked countries, contiguity, common language and colonial links. Finally, the estimated equation is:

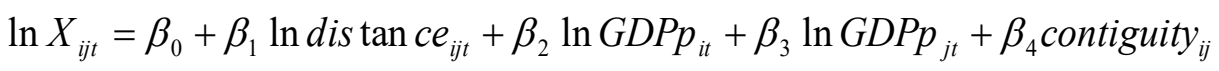

$+\beta_{5}$ commonofficiallanguage $_{i j t}+\beta_{6}$ commonethnolanguage $_{i j t}+\beta_{7}$ commoncolonizer $_{i j t}+\beta_{8}$ commoncurrency $_{i j t}$

$+\beta_{9}$ timeimport $_{i t}+\beta_{10}$ documents $_{i t}+\beta_{11}$ bordercompliance $_{i t}+\beta_{12} R T A_{i j t}+\delta_{i}+\lambda_{t}+\varepsilon_{i j t}$

The parameter $\beta_{0}$ represents the intercept while the parameters $\beta_{i}$ 's $(i \neq 0)$ are the coefficients. $\delta_{i}$ is the a country-specific effect (exporter or importer) and $\lambda_{t}$, the time-specific effect. $\varepsilon_{i j t}$ is the error term that is assumed to be normally distributed with mean zero. The definitions of variables and data sources are presented in appendix (table 1). The study includes the total of 49 African countries over the 2010-2015 periods. The choice of countries (the list of countries is in appendix) and years can be justified by the availability of the data. 


\section{Results}

Details results are presented in Table 1. All the estimation are corrected for heteroskedasticity and we used importer-time and exporter-time fixed effects to control for multilateral resistances.

Table 1. Estimation Results

\begin{tabular}{|c|c|c|c|c|c|}
\hline & (1) & (2) & (3) & (4) & (5) \\
\hline \multirow[t]{2}{*}{ Distance } & -1.570 & 0.349 & & -0.024 & \\
\hline & $(0.127)^{* * *}$ & $(0.213)$ & & $(0.232)$ & \\
\hline \multirow[t]{2}{*}{ Common official language } & 0.638 & 1.184 & & 1.245 & \\
\hline & $(0.157)^{* * *}$ & $(0.323)^{* * *}$ & & $(0.388)^{* * *}$ & \\
\hline \multirow[t]{2}{*}{ Common colonizer } & 0.609 & 1.657 & & 1.609 & \\
\hline & $(0.182)^{* * *}$ & $(0.323)^{* * *}$ & & $(0.371)^{* * *}$ & \\
\hline \multirow[t]{2}{*}{ Common currency } & 0.643 & 0.265 & & 0.282 & \\
\hline & $(0.274)^{* *}$ & $(0.477)$ & & $(0.530)$ & \\
\hline \multirow[t]{2}{*}{ Contiguity } & 1.268 & 1.661 & & 2.279 & \\
\hline & $(0.225)^{* * *}$ & $(0.414)^{* * *}$ & & $(0.539)^{* * *}$ & \\
\hline \multirow[t]{2}{*}{ RTA } & 1.216 & 1.895 & 3.661 & & \\
\hline & $(0.174)^{* * *}$ & $(0.369)^{* * *}$ & $(0.137)^{* * *}$ & & \\
\hline \multirow[t]{2}{*}{ GDP per capita } & & & & -0.065 & \\
\hline & & & & $(0.172)$ & \\
\hline \multirow[t]{2}{*}{ Time to import (days) } & & & & -0.088 & -0.452 \\
\hline & & & & $(0.331)$ & $(0.594)$ \\
\hline \multirow[t]{2}{*}{ Document(number) } & & & & -2.647 & 0.195 \\
\hline & & & & $(1.287)^{* *}$ & $(2.024)$ \\
\hline \multirow[t]{2}{*}{ Border compliance (hours) } & & & & -0.212 & -0.787 \\
\hline & & & & $(0.157)$ & $(0.477)^{*}$ \\
\hline Exporter-time fixed effects & Yes & Yes & Yes & Yes & Yes \\
\hline Importer -time fixed effects & Yes & Yes & Yes & Yes & Yes \\
\hline country-pair fixed effects & No & No & Yes & Yes & Yes \\
\hline Adj R-squared & 0.6 & 0.2 & 0.6 & 0.1 & 0.4 \\
\hline Observations & $7,504.00$ & $7,505.00$ & $7,504.00$ & $1,215.00$ & $1,215.00$ \\
\hline
\end{tabular}

The notations $* p<0.1 ; * *<0.05 ; * * * p<0.01$ denote significance at 10,5 and 1 percent levels respectively. Standard deviation clustered by country pair are in parentheses.

Source: Author's calculation

Column (1) presents the results of OLS estimation. The results show that the traditional gravity variables are statistically significant and have the expected signs. The distance is negatively significant at any conventional level confirming that distance is a significant 
impediment to bilateral trade (Head and Mayer, 2013; 2014). In fact, a 10 per cent increase in distance between two African countries cuts their trade, on average, by 15 per cent. The impact of sharing a common border, speaking the same official language, and sharing colonial ties and common currency are positive and statistically significant, in line with the literature (Melitz, 2008; Melitz and Toubal, 2014). Similarly, the Regional Trade Agreement (RTA) has a positive and significant effect suggesting that, everything been equal, RTA increases trade between member countries as documented by Anderson and Yotov (2016).

The PPML estimation results are reported in column (2). The traditional gravity variables remain statistically significant except for distance and common currency. However, previous estimations can suffer for endogeneity problem due to the omitted variable. According Baier and Bergstrand (2007), the estimates of the RTAs impact on trade obtained without proper account for endogeneity are biased downward. After controlling for endogeneity by using the country-pair fixed effects, the RTA remain statistically significant as reported in column (3).

In column (4) and (5), the estimated coefficients of our explanatory variables of main interest, Document (the number of documents required to import goods) and Border compliance (hours)are highly statistically significant and have a negative sign. This suggest that the 1 per cent increase in import documents number would, on average, lead to import volumes being diminished by 26,47 per cent. Similarly, the 1 per cent increase in border compliance would, on average, lead to import volumes being diminished by 7,87 per cent.

In other words, the trade procedures caused by the number of document to import and border compliance do indeed have a significantly negative effect on trade volumes. It follows that a country which reforms its trade procedures so that the number of documents to import and the time delays at the border are decreased could expect to see increased import volumes.

\section{Conclusion}

The purpose of this paper has been to evaluate and analyze the effects of inefficient trade procedures on trade volumes between African countries. For this aim, we use gravity model. The model includes a total of 49 African countries over the 2010-2015 periods. Our descriptive analysis shows that the intra-African trade ratio is low compared with other regions in the world. Among the factors holding back the intra-African trade figure prominently: the document requirements, the cumbersome border-crossing procedures and delays. For instance, we need in average ten days to clear direct exports through customs in Sub-Saharan Africa and on average eight documents to import.

Our econometric analysis found that trade procedures such as the number of documents required to import goods and Border compliance negatively affect trade volume in Africa. The policy implications of our results are important for the implementation of AfCFTA. In general, trade facilitation measures as a whole will help African countries to improve their trade performance. In particular, there is a need of harmonization of trade procedures. This include the harmonization of documents in number and in forms, and the streamlining of customs procedures. 


\section{References}

AfDB (African Development Bank), AU (African Union) \& ECA (Economic Commission for Africa) 2013). Assessing Regional Integration in Africa VI: Harmonizing Policies to Transform the Trading Environment. Addis Ababa, Ethiopia. https://doi.org/10.18356/5d7bf72c-en

African Union (2013). Action plan for boosting intra-African trade. https://doi.org/10.4060/cb3172en

Anderson, J.E., \&Van Wincoop, E. (2003). Gravity with Gravitas: A Solution to the Border Puzzle. American Economic Review, 93(1), 170-192.https://doi.org/10.1257/000282803321455214

Anderson, J. E., \& Yotov, Y. V. (2016). Terms of Trade and Global Efficiency Effects of Free Trade Agreements, 1990-2002. Journal of International Economics, 99(C), 279-298. https://doi.org/10.1016/j.jinteco.2015.10.006

Arvis, J.-F., Duval, Y., Shepherd, B., \& Utoktham, C. (2013). Trade Costs in the Developing World: 1995-2010. Policy Research Working Paper 6309. World Bank Washington, DC. https://doi.org/10.1596/1813-9450-6309

Baier, S. L., \& Bergstrand, J. H. (2007). Do Free Trade Agreements Actually Increase Members' International Trade? Journal of International Economics, 71(1), 72-95. https://doi.org/10.1016/j.jinteco.2006.02.005

Bourdet, Y., \& M. Persson (2012), Completing the European Union Customs Union: The Effects of Trade Procedure Harmonization. Journal of Common Market Studies, 50(2), 300-314. https://doi.org/10.1111/j.1468-5965.2011.02203.x

Djankov, S., Freund, C., \& Pham, C.S. (2010), Trading on Time. Review of Economics and Statistics, 92(1), 166-173.https://doi.org/10.1162/rest.2009.11498

Donaldson, D., Jinhage, A., \& Verhoogen, E. (2017). Beyond borders: Making transport work for African trade. Growth Brief, International Growth Centre, March 2017.

ECA (Economic Commission for Africa) (2016). Brief for the Office of the Executive Secretary on Regional Integration and the Continental Free Trade Area. African Trade Policy Centre. Addis Ababa.

Economic and Social Commission for Asia and the Pacific(ESCAP) (2013). International Supply Chain Connectivity (ISCC) Database: Explanatory Note for Users.

Freund, C. L. \& Rocha, N. (2010). What Constrains Africa's Exports?. Policy Research Working Paper No 5184. Washington DC: World Bank. https://doi.org/10.1596/1813-9450-5184

Head, K. (2003), Gravity for beginners. mimeo, University of British Columbia.

Head, K., \& Mayer, T. (2013). What Separates Us? Sources of Resistance to Globalization. 
Canadian Journal of Economics, 46(4), 1196-1231.https://doi.org/10.1111/caje.12055

Head, K., \& Mayer, T. (2014). Gravity Equations: Workhorse, Toolkit, and Cookbook. In G. Gopinath, E. Helpman \& K. Rogoff (Eds.), Handbook of International Economics, 4. Oxford: Elsevier B. V. https://doi.org/10.1016/b978-0-444-54314-1.00003-3

Hummels, D. L., \&Schaur, G. (2013). Time as a Trade Barrier. American Economic Review 103(7), 2935-2959.https://doi.org/10.1257/aer.103.7.2935

Kim, S., Lee H., \& Park, I. (2004). Measuring the Impact of APEC Trade Facilitation: A Gravity Analysis". Paper presented in the Reunion of the Economic Committee of the APEC. Santiago, Chili.

Kouty, M. (2018), Trading costs in Africa: does international supply chain connectivity matter? Journal of Economic Development, 43(2), 85-102. https://doi.org/10.35866/caujed.2018.43.2.005

Melitz, J. (2008). Language and Foreign Trade. European Economic Review, 52(4), 667-699. https://doi.org/10.1016/j.euroecorev.2007.05.002

Melitz, J., \& Toubal, F. (2014). Native Language, Spoken Language, Translation and Trade. Journal of International Economics, 93(2), 351-363. https://doi.org/10.1016/j.jinteco.2014.04.004

Mevel. S., \& Karingi, S. (2012). Deepening regional integration in Africa: A computable general equilibrium assessment of the establishment of a continental free trade area followed by a continental customs union. Presented at the seventh African Economic Conference. 30 October to 2 November. Kigali. https://doi.org/10.18356/fbd43b1f-en

Moïsé, E., \& Sorescu, S. (2013). Trade Facilitation Indicators: The Potential Impact of Trade Facilitation on Developing Countries Trade. OECD Trade Policy Papers. 144. OECD Publishing. https://doi.org/10.1787/5k4bw6kg6ws2-en

Novy, D. (2013). Gravity Redux: Measuring International Trade Costs with Panel Data. Economic Inquiry, 51(1), 101-121.https://doi.org/10.1111/j.1465-7295.2011.00439.x

Seetanah, B., Sannassee, R. V., \& Fauzel, S. (2016). Trade facilitation and trade flows: Evidence from Africa. In WTO (Ed.), Trade costs and inclusive growth (pp. 200-220). Geneva, Switzerland. https://doi.org/10.30875/49648549-en

United Nations Economic Commission for Africa, African Union \& African Development Bank (2017). Assessing Regional Integration in Africa VIII: Bringing the Continental Free Trade Area About. Addis Ababa, Ethiopia. https://doi.org/10.18356/06269c87-en

UNCTAD (2019). The Economic Development in Africa Report 2019: Made in Africa Rules of Origin for Enhanced Intra-African Trade. New York and Geneva. https://doi.org/10.18356/c5dd68cb-en

Zaki, C. (2007). Does Trade Facilitation Matter in Bilateral Trade? University of Paris 1, mimeo. 
World Bank (2020). The African Continental Free Trade Area: Economic and Distributional Effects. Washington, DC: World Bank. https://doi.org/10.1596/978-1-4648-1559-1

World Trade Organization (WTO) (2015). World Trade Report 2015: Speeding Up Trade: Benefits And Challenges of Implementing the WTO Trade Facilitation Agreement. Geneva, Switzerland. https://doi.org/10.30875/3f513c80-en

\section{Appendix}

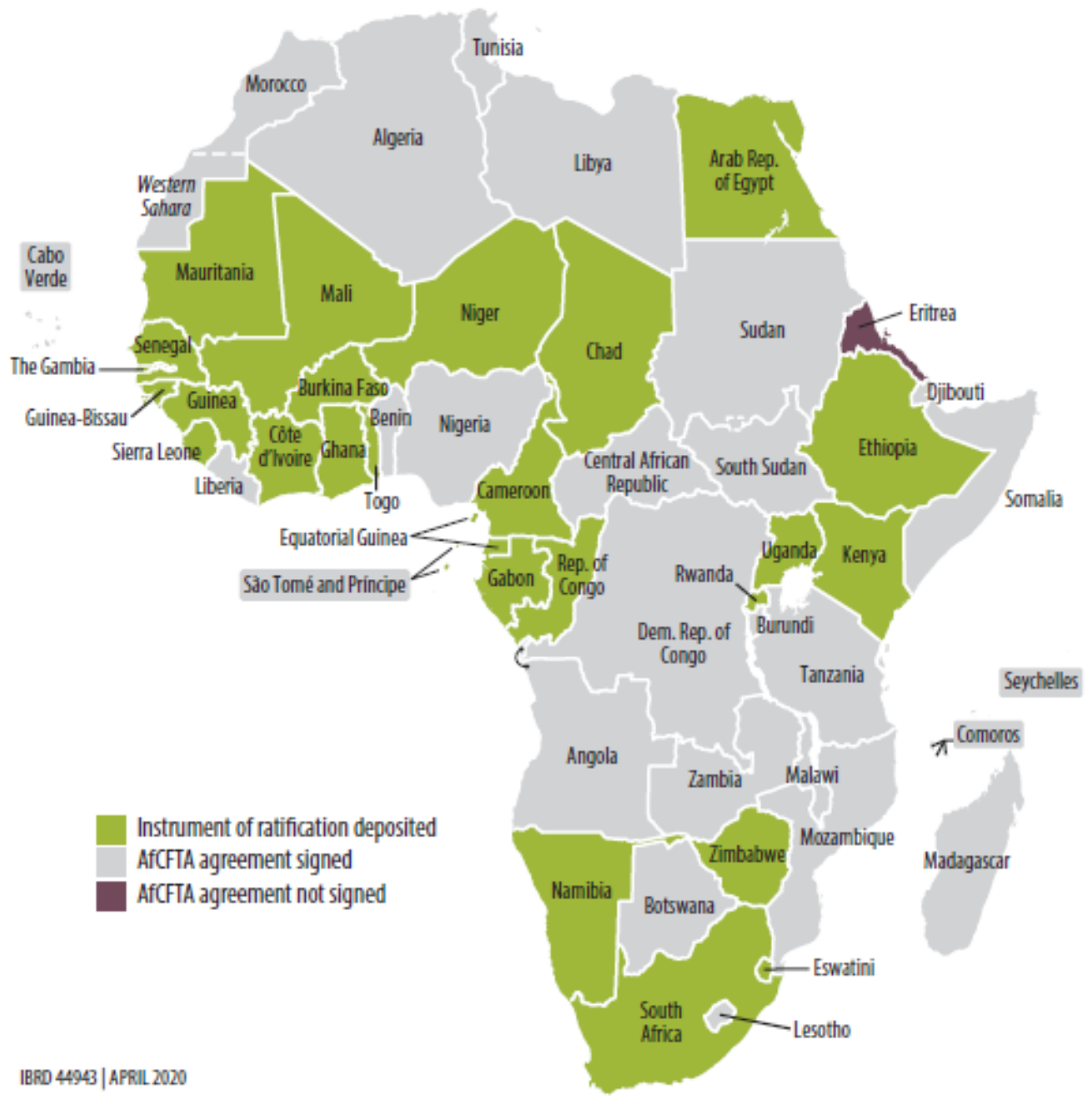

Figure A1. Members of AfCFTA by statute

Source: World Bank(2020). 
Table A1: Definitions of Variables and Data Sources

\begin{tabular}{|c|c|c|}
\hline Variables & Définitions & Sources \\
\hline Import & Nominal import(US dollars) & $\begin{array}{lrr}\text { UN } & \text { Comtrade } & \text { database } \\
\text { HS6- } & \text { 1988/1992 } & \end{array}$ \\
\hline $\begin{array}{l}\text { GDPp } \\
\text { Distance }\end{array}$ & Gross Domestic Product per capita & $\begin{array}{l}\text { World Bank } \\
\text { CEPII }\end{array}$ \\
\hline & Great circle distance between the two pr & \\
\hline $\begin{array}{l}\text { Border compliance } \\
\text { (Hours) }\end{array}$ & $\begin{array}{l}\text { Time and cost associated with compliance } \\
\text { with the economy's customs regulations and } \\
\text { with regulations }\end{array}$ & World Bank \\
\hline Documents & $\begin{array}{l}\text { Number of documents required to import } \\
\text { goods. }\end{array}$ & World Bank \\
\hline $\begin{array}{l}\text { Common Colonizer } \\
\text { (settler) }\end{array}$ & $\begin{array}{l}\text { Dummy variable equal to unity if countries } i \\
\text { and } j \text { were colonized by the same colonizer. }\end{array}$ & CEPII \\
\hline Contiguity & $\begin{array}{l}\text { Dummy variable equal to unity if countries } \mathrm{i} \\
\text { and } \mathrm{j} \text { share a common land border. }\end{array}$ & CEPII \\
\hline $\begin{array}{l}\text { Common Official } \\
\text { Language }\end{array}$ & $\begin{array}{l}\text { Dummy variable equal to unity if countries } i \\
\text { and } j \text { share a common official language. }\end{array}$ & CEPII \\
\hline $\begin{array}{l}\text { Common Ethnic } \\
\text { Language }\end{array}$ & $\begin{array}{l}\text { Dummy variable equal to unity if countries } i \\
\text { and } j \text { share a common ethnic language. }\end{array}$ & CEPII \\
\hline RTA & $\begin{array}{l}\text { Dummy variable equal to unity if countries } i \\
\text { and } j \text { are members of the same RTA. }\end{array}$ & WTO \\
\hline
\end{tabular}

Source: Author

\section{List of countries}

Algeria, Angola, Benin, Botswana, Burkina Faso, Burundi, Cameroon, Cape Verde, Central African Republic, Chad, Congo, Rep., Cote d'Ivoire, Djibouti, Egypt, Arab Rep., Equatorial Guinea, Eritrea, Ethiopia, Gabon, Gambia, Ghana, Guinea, Guinea-Bissau, Kenya, Lesotho, Liberia, Libya, Madagascar, Malawi, Mali, Mauritania, Mauritius, Morocco, Mozambique, Namibia, Niger, Nigeria, Rwanda, Senegal, Sierra Leone, Somalia, South Africa, Swaziland, Tanzania, Togo, Tunisia, Uganda, Uruguay, Zambia, Zimbabwe 


\section{1) Macrothink}

Table A2: Summary of Statistics

\begin{tabular}{lccccc}
\hline \multicolumn{1}{c}{ Variables } & Observations & Mean & $\begin{array}{c}\text { Standard } \\
\text { deviation }\end{array}$ & Minimum & Maximum \\
& \multicolumn{7}{c}{ Time-variant bilateral data } \\
\hline & 7505 & 49107.66 & 293153.6 & 0.00 & 5135808 \\
\hline Export & \multicolumn{2}{c}{ Country specific data } \\
\hline \multicolumn{7}{c}{$4.50 \mathrm{e}+13$} & $4.09 \mathrm{e}+14$ & $1.01 \mathrm{e}+10$ & $9.09 \mathrm{e}+15$ \\
\hline GDP_per capita & 7492 & 9.621626 & 4.370928 & 9.00 & 34.7625 \\
Time to import (days) & 6372 & $5.10 \mathrm{e}+12$ & $2.03 \mathrm{e}+14$ & 5.00 & $8.11 \mathrm{e}+15$ \\
Document to import (number) & 6366 & 11.88242 & 3.788926 & 10 & 29.9125 \\
Time to export (days) & 6372 & 19.12394 & 30.67905 & 4 & 715 \\
Document to export (number) & 6366 & 323.9645 & 12655.34 & -1.00 & 612375 \\
Border compliance export (hours) & 2341 & 64.93165 & 252.2236 & -1.00 & 11875 \\
Border compliance import (hours) & 2341 & Time-invariant bilateral data & & 11658.8 \\
\hline \multicolumn{7}{c}{} & 7505 & 3731.617 & 2102.266 & 105.1806 & 1.00 \\
\hline Distance & 7505 & 0.0935376 & 0.2912038 & 0.00 & 1.00 \\
Contiguity & 7505 & 0.0803464 & 0.2718469 & 0.00 & 1.00 \\
Common currency & 7505 & 0.2834111 & 0.4506843 & 0.00 & 1.00 \\
Common colonizer & 7505 & 0.4747502 & 0.4993953 & 0.00 & 1.00 \\
Common Official Language & 7505 & 0.2998001 & 0.4582008 & 0.00 & \\
RTA & & & &
\end{tabular}

\section{Notes}

Note 1. These are the Arab Maghreb Union (AMU), Economic Community of West African States (ECOWAS), East African Community (EAC), Intergovernmental Authority on Development (IGAD), Southern African Development Community (SADC), Common Market for Eastern and Southern Africa (COMESA), Economic Community of Central African States (ECCAS) and the Community of Sahel-Saharan States (CEN-SAD).

Note 2. See figure A1 in appendix for the members of AfCTA.

Note 3. http://dataank.worldbank.org/data/source/world-development-indicators.

Note 4. UNCTADSTAT (http://unctadstat.unctad.org/wds/TableViewer/tableView.aspx.).

Note 5. http://unctadstat.unctad.org/wds/TableViewer/tableView.aspx

Note 6. Anderson and Van Wincoop (2003) call these price indices multilateral resistance variables.

\section{Copyright Disclaimer}

Copyright for this article is retained by the author(s), with first publication rights granted to the journal.

This is an open-access article distributed under the terms and conditions of the Creative Commons Attribution license (http://creativecommons.org/licenses/by/3.0/). 